\title{
Toxicity of Machaerium opacum (Fabaceae) Leaf Extracts Against Fall Armyworm (Spodoptera frugiperda (J. E. Smith) (Lepidoptera: Noctuidae)
}

\author{
Edley F. B. Bezerra ${ }^{1}$, Renato G. Santos ${ }^{2}$, Antônio C. S. Menezes ${ }^{2}$, André C. S. Almeida ${ }^{3}$, Flávio G. Jesus ${ }^{3}$, \\ Ednaldo C. Rocha ${ }^{1} \&$ Márcio S. Araújo ${ }^{1}$ \\ ${ }^{1}$ Universidade Estadual de Goiás, Câmpus Ipameri, Ipameri, GO, Brazil \\ ${ }^{2}$ Universidade Estadual de Goiás, Câmpus Anápolis, Anápolis, GO, Brazil \\ ${ }^{3}$ Instituto Federal Goiano, Campus Urutaí, Urutaí, GO, Brazil \\ Correspondence: Márcio da Silva Araújo, Universidade Estadual de Goiás, Câmpus Ipameri, Ipameri, GO, \\ Brazil. Tel: 55-64-3491-3801. E-mail: marcio.araujo@ueg.br
}

Received: April 10, 2019

Accepted: May 24, 2019 Online Published: July 15, 2019

doi:10.5539/jas.v11n10p292

URL: https://doi.org/10.5539/jas.v11n10p292

\begin{abstract}
Secondary plant metabolites have been widely studied as pest control agents. In this paper we report secondary compounds present in Machaerium opacum leaves, as well as the toxicity of different fractions of the extract of this plant to fall armyworm (Spodoptera frugiperda (J. E. Smith) (Lepidoptera: Noctuidae)) under laboratory conditions. Crude extracts were obtained by means of ethanol. Refractionation was carried out with the solvents hexane, dichloromethane, methanol and ethyl acetate. By means of preliminary phytochemical prospection, starting with the ethanolic extract, flavonoid, triterpene, anthraquinone, coumarin, tannin and steroid compounds were identified. In the ethanolic fractions, triterpene compounds were identified in a mixture ( $\alpha$-amyrin and $\beta$-amyrin), as well as lupeol and the acyclic diterpene alcohol, phytol. In methanolic fractions, the flavonoid rutin was found. In the dichloromethane fraction, the flavonoid mucronulatol and its isomer, isomucronulatol, were found. Extracts of $M$. opacum did not present an antifeedant effect on the larvae of $S$. frugiperda. However, all fractions of the extracts tested promoted significant antibiosis effects (reduced weight in the larvae and pupa, larval and pupal mortality and prolongation of the adult phase) on the test population of S. frugiperda. Therefore, our results showed the insecticidal potential of leaf extracts of M. opacum against S. frugiperda.
\end{abstract}

Keywords: botanical insecticide, phytochemical prospecting, antifeedant, antibiosis, Lepidoptera

\section{Introduction}

The fall armyworm S. frugiperda (J. E. Smith) (Lepidoptera: Noctuidae) is an economically important pest of maize and other crops of tropical and subtropical America (Andrews, 1980; Martínez et al., 2017). Currently, the main methods used for its control are organosynthetic insecticides and transgenic plants. However, routine spraying with insecticides from the same group of action, associated with overlapping or successive crops that include host plants, exposes the populations of $S$. frugiperda to high selection pressure by insecticides and Bacillus thuringiensis (Bt) proteins, which jeopardizes the available control tactics (O. Bernardi, D. Bernardi, Hirikoshi, \& Omoto, 2016). Therefore, alternative methods that are in line with integrated management programs for this pest, such as the use of insecticidal plants, should be studied (Silva et al., 2016).

Insecticidal plants generally present a wide spectrum of control among insect pests, are relatively specific in their mode of action, degrade rapidly, usually have a low environmental impact and are fairly safe for non-target organisms (Aguiar-Menezes, 2005; Upadhyay, 2012; Sousa Neto et al., 2018). This makes plant extracts potential pest control agents (Dequech, Sausen, Lima, \& Egewarth, 2008; Bettiol \& Morandi, 2009). It is important to highlight that death is not always the only consequence of the use of these botanical substances, since they can also be efficient in promoting only the inhibition or reduction of food ingestion, or may cause sterility or deformity in the insect (Gonzáles-Coloma, Reina, Gutiérrez, \& Fraga, 2002; Dequech, Sausen, Lima, \& Egewarth, 2008; Baskar et al., 2009; Baskar \& Ignacimuthu, 2012; Sousa Neto et al., 2018). As well as the afore mentioned favorable aspects for the use of insecticidal plants compared to synthetic insecticides, Ferraz, 
Lopes, and Amora (2008) mention the capacity of the plant to produce a range of secondary metabolites that pests and pathogens do not manage to inactivate.

Phytochemicals produced by the plant's secondary metabolism are the main agents that control herbivory, and their distribution pattern varies considerably among plant families (Koul, 2005). According to Leatemia and Isman (2004), the botanical families with the greatest insecticidal potential are Meliaceae, Rutaceae, Asteraceae, Annonaceae, Labiatae and Canellaceae. In addition to these families, Fabaceae have been mentioned for their insecticidal properties (Amen, Marzouk, Zaghloul, \& Afifi, 2015; Santos, 2017; Souza et al., 2017).

The Fabaceae family includes about 727 genera and more than 19,000 plant species (Lewis, 2005). It is a botanical group of enormous social and economic importance, because its various species are used in food, oil production, fibers, fuels, timber, medicines and chemical products, especially in the use of phytochemicals in the agrochemical, pharmaceutical and food industries (Duke, 1981). Its broad use in phytochemical and pharmacological studies is due to the presence of numerous secondary metabolites in its constitution (Wink, 2013). The genus Machaerium belongs to the Fabaceae family and includes the species that are popularly known as "Jacarandas" in Brazil. It is one of the largest genera of tropical trees in the world, and has approximately 130 species (Lewis, 2005). Various species from this genus have long been used pharmaceutically and are therefore known for their biological and medicinal action (Amen, Marzouk, Zaghloul, \& Afifi, 2015). Machaerium opacum, popularly known as "Jacarandá-do-Cerrado" is an arboreal species native to Brazil, and it occurs throughout the Cerrado (savanna) regions of Brazil, including in some states in the North, Northeast, Southeast and, especially, the Midwest (Flora do Brasil, 2018). Nowadays, every plant that is born in the natural areas of the Brazilian Cerrado, even in those protected by law, is already born threatened to disappear. The disorderly exploitation of this specie for the most varied purposes endangers its survival. The purpose of our study is to know other properties of the plant and to warn about the importance of its preservation.

This work aimed to record the occurrence of potential insecticidal compounds in leaves of M. opacum, as well as to evaluate the toxicity of leaf extracts fractions of this plant on $S$. frugiperda raised in the laboratory on a natural diet of maize leaves.

\section{Materials and Methods}

\subsection{Preparation and Phytochemical Prospection of Plant Extracts}

M. opacum plants were gathered in the Cerrado biome, near Anápolis city, Goiás state, Brazil (Lat. $16^{\circ} 19^{\prime}$ S; Long. $48^{\circ} 57^{\prime} \mathrm{W}$ ). From these plants, around $4.4 \mathrm{~kg}$ of the leaves of the upper third were collected. The plant material was oven-dried $\left(45^{\circ} \mathrm{C}\right)$ for 48 hours and ground in a knife-mill. The ground leaves were then immersed in $95 \%$ ethanol (5 Liters).This material was macerated cold, and later filtered and concentrated in a rotary evaporator, producing ethanolic extracts of M. opacum leaf (MOLEE). These extracts, with mass equal to 346.06 grams, were fractionated, employing solvents in a gradient of increasing polarity (hexane $<$ dichloromethane $<$ ethyl acetate $<$ methanol). Microcrystalline cellulose D was incorporated into the ethanolic extract, and vacuum filtration was performed.

Four leaf fractions were obtained; namely, hexanic leaf extracts of $M$. opacum (MOLEH), with mass equal to 68.66 grams, dichloromethanic leaf extracts of M. opacum (MOLED) with mass equal to 8.04 grams, ethyl acetate leaf extracts of M. opacum (MOLEEA) with mass equal to 2.71 grams, and the methanolic leaf extract of E. pumila (MOLEM), with mass equal to 120.63 grams. Both ethanolic extracts and all the M.opacum leaf fractions were stored in the dark under refrigeration until further use in the biological tests. In this study, the toxicity of MOLED and MOLEEA was not verified in relation to the insect S. frugiperda, because there was an insufficient quantity of these extracts for use in the biological tests. However, it was possible to isolate and identify possible insecticidal substances.

Terpenes (cardioactive heterosides and saponins), nitrogen compounds (alkaloids) and phenolic compounds (flavonoids, anthraquinones, simple phenols, coumarins and tannins), were analyzed in M. opacum leaf fractions (MOLEE) following the method adapted from Matos and Matos (1989), Matos (2009), Simões (2010), Costa (2001), and Souza et al. (2017). The analytical procedures used for the identification of the secondary metabolites were as follows: Flavonoids-colorimetric (Shinoda, Sodium Hydroxide and Ferric Chloride) and fluorescence under ultraviolet light (Oxalo-boric, Sulfuric Acid, Aluminum Chloride and Potassium Hydroxide); Anthraquinones-Bornträger Indirect; Coumarins-Fluorescence under ultraviolet light potentiated with sodium hydroxide 1N; Cardioactive Heterosides-Liebermann-Burchard, Pesez, Keller-Kiliam and Kedde; Tannins-precipitation (Gelatin, Quinine Sulfate, Brucine Sulfate, Copper Acetate and Ferric Chloride) and Colorimetric (Sodium Hydroxide); Alkaloids-Mayer, Dragendorff, Bouchardat, Bertrand and Hager and Tannic Acid; Saponins-Shake foam. 
By means of column chromatography, fractionation and successive refractionations were performed for MOLEH, MOLED, MOLEEA and MOLEM. The identification of possible compounds with biological activity was carried out by infra-red (IV) analyses, nuclear magnetic resonance (NMR ${ }^{1} \mathrm{H}$ and $\mathrm{NMR}{ }^{13} \mathrm{C}$ ), heteronuclear single quantum coherence (HSQC) spectroscopy, heteronuclear multiple bond correlation (HMBC) spectroscopy, and gas chromatography coupled to mass spectrometry (CG/MS). More details on the extraction and chemical analysis of the chemotypes of M. opacum can be consulted in Santos (2017). In the present study, the focus will be mainly on evaluating the insecticidal effect of the extracts.

\subsection{Biological Assays}

The biological tests were carried out in the Laboratory of Agricultural Entomology at the State University of Goiás, in Ipamerí, Goiás state, Brazil, in a climate-controlled room with a temperature of $25 \pm 2{ }^{\circ} \mathrm{C}$, relative humidity of $70 \pm 10 \%$ and photoperiod of 12 hours.

The concentrations of all the fractions of the M. opacum extracts (MOLEE, MOLEH and MOLEM) used in the bioassays were: $0.1 ; 1.0 ; 1.5 ; 3.0 ; 5.0$ and $10.0 \%$. The solvent used was acetone + water, in the proportion $1: 1$. In preliminary tests, this solvent was the one that best dissolved the extracts. Furthermore, in preliminary tests this solvent did not repel the larvae of S. frugiperda, after it had evaporated from the maize leaves that were to be offered to these larvae.

\subsection{Antifeedant Activity}

The S. frugiperda larvae used in the experiment were obtained from mass-produced eggs, following the methodology of Kasten Junior, Precetti, and Parra (1978), from artificial diet. Third-instar larvae of S. frugiperda were kept without any food for a period of three hours, until biological tests began. The choice of third instar larvae was due to reduced mobility of first and second instar larvae to host plants in the experimental arena After this period, lots of 19 individuals were released in the central region of a cylindrical cardboard box measuring $34.5 \mathrm{~cm}$ in diameter and $6.0 \mathrm{~cm}$ in height, lined with filter paper slightly moistened with distilled water. Under this filter paper, near its edges, the 18 treatments (leaf sections treated with the respective concentrations of each extract: MOLEE, MOLEH and MOLEM) and the blank (leaf sections treated only with acetone and water) were placed equidistantly. The treatment consisted of using tweezers to dip the fragment of maize leaf into receptacles containing the extracts of $M$. opacum, which were dried in the shade before being offered to the larvae. The leaf fragments $\left(4.0 \mathrm{~cm}^{2}\right)$ were obtained using a circular metal hole-puncher. After the larvae were released, the arena was covered with a transparent glass sheet, which allowed observers to view the foraging behavior of the animals. The attractiveness of leaves with different extracts was evaluated by counting the larvae in each leaf treatment at 1, 3, 5, 10, 15, 30, 60, 120,360, 720 and 1440 minutes after release. The experimental design adopted in this test was randomized blocks, with 19 treatments and 10 repetitions.

\subsection{Antibiosis Activity}

The $S$. frugiperda larvae used in the experiment were also obtained from artificial rearing. After hatching, the larvae were put individually into plastic cups with capacity of $250 \mathrm{~mL}$, containing parts of the maize plant RK 9014, treated with plant extracts, as described in the previous experiment. The bottom of the plastic receptacle was lined with filter paper slightly moistened with distilled water. Each larvae was offered a fraction of maize leaf treated with the solution of each treatment. After the leaf for feeding the larvae was in place, the pots were closed with plastic lids and distributed on shelves in the laboratory.

The pots were cleaned daily, removing the excrement and changing the filter paper. The maize leaves from each treatment were also replaced each day. At the moment of pot maintenance, the number of dead larvae was recorded, a procedure that was adopted until pupae developed. All the surviving larvae were weighed at 10 days after the start of the experiment.

Each pupa was weighed 24 hours after it developed, and it was returned to its respective pot for emergence as an adult. After adult insects had emerged, they were kept in the same pots they had used as larvae, but without any type of food.

The biological variables evaluated were: period and viability of larvae, weight of larvae at 10 days, period and viability of pupae, weight of pupae at 24 hours, longevity of adults and total cycle. The design adopted for this evaluation was entirely randomized, with 19 treatments and 30 repetitions.

\subsection{Statistical Analyses}

The data for larval and pupal mortality, proportion of males and of defective adults and the data from the choice test performed for attractiveness were submitted to analysis of deviance from a binomial generalized linear 
model. The treatments were compared at intervals of $95 \%$ confidence for the proportions evaluated. The dates larval weight (10 days after hatching), pupal weight (24 hours after formation), pupal period, adult longevity, larval period and total life cycle were arranged in a ranks to meet the assumptions of normality and homogeneity of variance. The dates were submitted to analysis of variance and the Skott-Knott test, according to Jelihovschi, Faria, \& Allaman (2014). The figures were performed with the aid of the plot function of the R program. All statistical analyzes were done using R version 3.5 software (R Core Team, 2018).

\section{Results}

In phytochemical prospection of the leaves of M. opacum, the following secondary metabolites were detected: flavonoids, triterpenes, anthraquinones, coumarins, tannins and steroids. Alkaloids and saponins were not detected. In MOLEH, analyses of IV, RMN ${ }^{1} \mathrm{H}$ and $\mathrm{RMN}{ }^{13} \mathrm{C}$ indicated the presence of the following compounds: mixed triterpenes ( $\alpha$-amyrin and $\beta$-amyrin), lupeol $\left(\mathrm{C}_{30} \mathrm{H}_{50} \mathrm{O}\right)$ and the acyclic diterpene alcohol, phytol $\left(\mathrm{C}_{20} \mathrm{H}_{40} \mathrm{O}\right)$. In MOLEM, analyses of RMN ${ }^{1} \mathrm{H}$ and $\mathrm{RM}{ }^{13} \mathrm{C}$ and of $\mathrm{HMBC}$ showed the presence of the flavonoid rutin $\left(\mathrm{C}_{27} \mathrm{H}_{30} \mathrm{O}_{16}\right)$. In MOLED, using techniques similar to those adopted for MOLEH and MOLEM, including the techniques HSQC and CG/MS, the substances mucronulatol $\left(\mathrm{C}_{17} \mathrm{H}_{18} \mathrm{O}_{5}\right)$ and its isomer, isomucronulatol, were found.No significant difference between the treatments was found, when the attractiveness of maize leaves was evaluated after treatment with different fractions and concentrations of M. opacum extracts in larvae of $S$. frugiperda (Deviance, $\mathrm{p}>0.05$ ).

The variables of weight of larvae and pupae were significantly influenced by all the treatments when compared to the control (Kruskal-Wallis, p value $<0.05$ ). The hexanic extract promoted the greatest reduction in the weight of larvae when compared to the methanolic and ethanolic extracts, in relation to pupal weight, no extract stood out. However, in general greater reductions in larval and pupal weight were observed for the higher concentrations (3.0, 5.0 and 10\%), except for methanolic (5\%) (Table 1).

Table 1. Larval weight (10 days after hatching) and pupal weight (24 hours after formation) of Spodoptera frugiperda fed on maize leaves treated with different concentrations (\%) of Machaerium opacum

\begin{tabular}{lllllll}
\hline \multirow{2}{*}{$\begin{array}{l}\text { Concentration of } \\
\text { extracts (\%) }\end{array}$} & \multicolumn{3}{c}{ Larval weight $(\mathrm{g})$} & \multicolumn{3}{c}{ Pupal weight $(\mathrm{g})$} \\
\cline { 2 - 7 } & \multicolumn{7}{c}{ Extract } \\
\cline { 2 - 7 } & $0.175 \mathrm{bA}$ & $0.180 \mathrm{bA}$ & $0.190 \mathrm{bA}$ & $0.145 \mathrm{cB}$ & $0.160 \mathrm{bA}$ & $0.150 \mathrm{cB}$ \\
1.0 & $0.190 \mathrm{bA}$ & $0.140 \mathrm{cB}$ & $0.195 \mathrm{bA}$ & $0.160 \mathrm{bA}$ & $0.150 \mathrm{bA}$ & $0.145 \mathrm{cA}$ \\
1.5 & $0.170 \mathrm{bA}$ & $0.152 \mathrm{cB}$ & $0.190 \mathrm{bA}$ & $0.130 \mathrm{cB}$ & $0.130 \mathrm{cB}$ & $0.160 \mathrm{bA}$ \\
3.0 & $0.110 \mathrm{~dB}$ & $0.080 \mathrm{eB}$ & $0.150 \mathrm{dA}$ & $0.095 \mathrm{dA}$ & $0.090 \mathrm{dA}$ & $0.110 \mathrm{dA}$ \\
5.0 & $0.155 \mathrm{cA}$ & $0.120 \mathrm{~dB}$ & $0.155 \mathrm{cA}$ & $0.130 \mathrm{cB}$ & $0.110 \mathrm{cC}$ & $0.160 \mathrm{bA}$ \\
10.0 & $0.150 \mathrm{cA}$ & $0.090 \mathrm{eB}$ & $0.160 \mathrm{cA}$ & $0.100 \mathrm{dA}$ & $0.105 \mathrm{dA}$ & $0.110 \mathrm{dA}$ \\
Control & $0.275 \mathrm{aA}$ & $0.275 \mathrm{aA}$ & $0.275 \mathrm{aA}$ & $0.290 \mathrm{aA}$ & $0.290 \mathrm{aA}$ & $0.290 \mathrm{aA}$ \\
\hline p-value & $<0.05$ & & & $<0.05$ & & Hexanic \\
\hline
\end{tabular}

Note. Rank means followed by the same letter in lowercase in the column or uppercase in the row do not differ between them (Kruskal-Wallis; $\mathrm{p}<0.05$ ).

The variables of duration of larval and pupal periods, adult longevity and total duration of the life cycle of $S$. frugiperda were significantly influenced by all the treatments when compared to the control. No highlighted influence of the concentration of the extract was confirmed for the variables of larval and pupal periods (Kruskal-Wallis p value $<0.001$ ) (Table 2). For adult longevity and total duration of life cycle, all the extracts, in their different concentrations, differed from the control. Among treatments, the one that promoted reduction of adult longevity and consequently reduction of total cycle duration was the hexanic extract (3.0\%) (Table 3). 
Table 2. Duration of larval and pupal periods, adult longevity and total cycle of Spodoptera frugiperda fed with maize leaves treated with different fractions and concentrations (\%) of Machaerium opacum

\begin{tabular}{|c|c|c|c|c|c|c|}
\hline \multirow{2}{*}{$\begin{array}{l}\text { Cooncentration of } \\
\text { extracts }(\%)\end{array}$} & \multicolumn{3}{|c|}{ Duration of larval period (days) } & \multicolumn{3}{|c|}{ Duration of pupal period (days) } \\
\hline & MOLEE & MOLEH & MOLEM & MOLEE & MOLEH & MOLEM \\
\hline 0.1 & $16.5 \mathrm{aA}$ & $16.0 \mathrm{bA}$ & $15.0 \mathrm{bA}$ & $8.0 \mathrm{bA}$ & $8.0 \mathrm{aA}$ & $9.0 \mathrm{aA}$ \\
\hline 1.0 & $18.0 \mathrm{aA}$ & $17.0 \mathrm{bA}$ & $15.0 \mathrm{bB}$ & $8.0 \mathrm{cB}$ & $9.0 \mathrm{aA}$ & $9.0 \mathrm{aA}$ \\
\hline 1.5 & $17.0 \mathrm{aA}$ & $17.0 \mathrm{bA}$ & $18.0 \mathrm{aA}$ & $8.0 \mathrm{cA}$ & $8.0 \mathrm{aB}$ & $8.0 \mathrm{bB}$ \\
\hline 3.0 & $16.0 \mathrm{aB}$ & $18.0 \mathrm{aA}$ & $18.0 \mathrm{aA}$ & $9.0 \mathrm{aA}$ & $9.0 \mathrm{aA}$ & $8.0 \mathrm{aA}$ \\
\hline 5.0 & $17.5 \mathrm{aA}$ & $16.0 \mathrm{bA}$ & $18.0 \mathrm{aA}$ & $7.5 \mathrm{cB}$ & $8.0 \mathrm{aA}$ & $8.0 \mathrm{bA}$ \\
\hline 10.0 & $18.0 \mathrm{aA}$ & $18.0 \mathrm{aA}$ & $15.0 \mathrm{bB}$ & $8.0 \mathrm{aA}$ & 8.0 a $\mathrm{A}$ & $9.0 \mathrm{aB}$ \\
\hline Control & $16.0 \mathrm{aA}$ & $16.0 \mathrm{bA}$ & $16.0 \mathrm{bA}$ & $9.0 \mathrm{aA}$ & $9.0 \mathrm{aA}$ & $9.0 \mathrm{aA}$ \\
\hline p-value & $<0.001$ & & & $<0.001$ & & \\
\hline
\end{tabular}

Note. *: Concetration of extracs (\%); MOLEE: ethanolic leaf extract of M. opacum. MOLEH: hexanic leaf extract of M. opacum. MOLLEM: metanolic leaf extract of M. opacum. Rank means followed by the same letter in lowercase in the column or uppercase in the row do not differ between them (Kruskal-Wallis; $p<0.05$ ).

Table 3. Adult longevity and total cycle of Spodoptera frugiperda fed with maize leaves treated with different fractions and concentrations (\%) of Machaerium opacum

\begin{tabular}{|c|c|c|c|c|c|c|}
\hline \multirow{2}{*}{$\begin{array}{l}\text { Cooncentration of } \\
\text { extracts }(\%)\end{array}$} & \multicolumn{3}{|c|}{ Adult longevity (days) } & \multicolumn{3}{|c|}{ Duration of total life cycle (days) } \\
\hline & MOLEE & MOLEH & MOLEM & MOLEE & MOLEH & MOLEM \\
\hline 0.1 & $14.0 \mathrm{bA}$ & $14.0 \mathrm{bA}$ & $15.0 \mathrm{bA}$ & $39.0 \mathrm{bB}$ & $38.0 \mathrm{bC}$ & $39.0 \mathrm{bA}$ \\
\hline 1.0 & $14.0 \mathrm{bB}$ & $14.0 \mathrm{bB}$ & $15.0 \mathrm{bA}$ & $38.0 \mathrm{bB}$ & $37.0 \mathrm{bC}$ & $39.0 \mathrm{bA}$ \\
\hline 1.5 & $13.5 \mathrm{cA}$ & $13.0 \mathrm{bA}$ & $13.0 \mathrm{cA}$ & $37.0 \mathrm{dA}$ & $38.0 \mathrm{bA}$ & $38.0 \mathrm{cA}$ \\
\hline 3.0 & $13.0 \mathrm{cA}$ & $6.00 \mathrm{dC}$ & $9.00 \mathrm{~dB}$ & $38.0 \mathrm{cA}$ & $32.5 \mathrm{cC}$ & $35.0 \mathrm{eB}$ \\
\hline 5.0 & $12.5 \mathrm{cB}$ & $14.0 \mathrm{bA}$ & $12.0 \mathrm{cB}$ & $37.0 \mathrm{dA}$ & $38.0 \mathrm{bA}$ & $38.0 \mathrm{cA}$ \\
\hline 10.0 & $11.0 \mathrm{~dB}$ & $11.0 \mathrm{cB}$ & $13.5 \mathrm{cA}$ & $36.0 \mathrm{eB}$ & $37.0 \mathrm{bA}$ & $36.5 \mathrm{dA}$ \\
\hline Control & $18.5 \mathrm{aA}$ & $18.5 \mathrm{aA}$ & $18.5 \mathrm{aA}$ & $44.0 \mathrm{aA}$ & $44.0 \mathrm{aA}$ & $44.0 \mathrm{aA}$ \\
\hline p-value & $<0.001$ & & & $<0.001$ & & \\
\hline
\end{tabular}

Note. MOLEE: ethanolic leaf extract of M. opacum. MOLEH: hexanic leaf extract of $M$. opacum. MOLLEM: metanolic leaf extract of $M$. opacum. Rank means followed by the same letter in lowercase in the column or uppercase in the row do not differ between them (Kruskal-Wallis; $\mathrm{p}<0.05$ ).

The variable proportion of dead larvae did not highlight any extract of $M$. opacum as showing a difference from the control treatment. In absolute terms, the two highest concentrations of MOLEH stood out (Figure 1). The variable proportion of dead pupae made MOLEH and MOLEE stand out. Pupal mortality that was different from the control did not occur in any of the concentrations of MOLEM (Figure 2). 


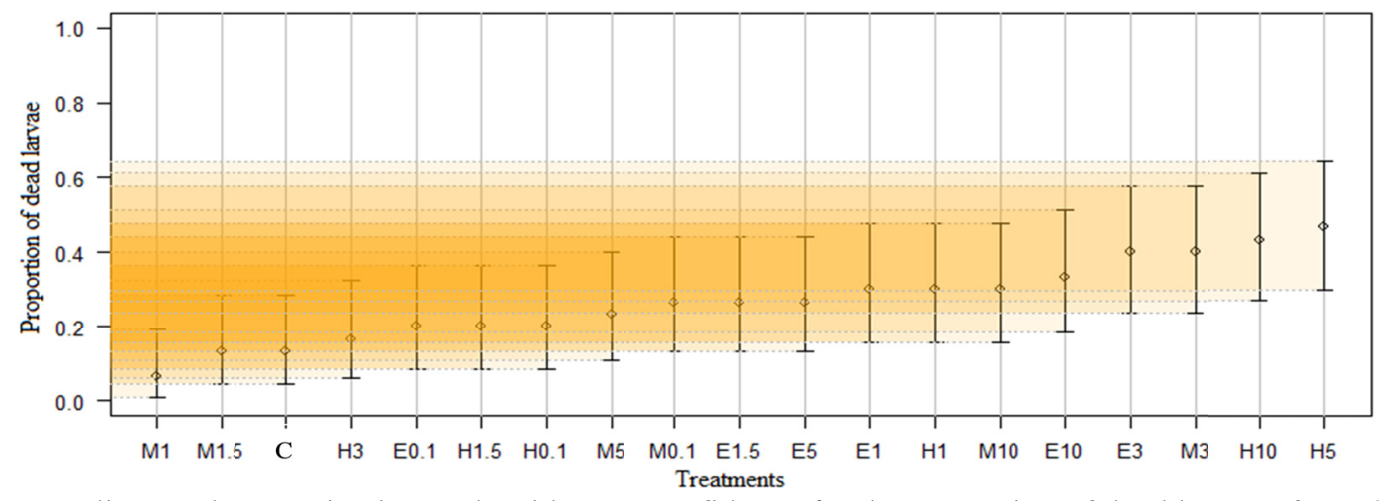

Figure 1. Medians and respective intervals with 95\% confidence for the proportion of dead larvae of Spodoptera frugiperda for each treatment. M0.1; M1; M1.5; M3; M5 and M10 correspond, respectively, to the treatments with methanolic leaf extract of Machaerium opacum (MOLEM) in concentrations of $0.1 ; 1.0 ; 1.5 ; 3.0 ; 5.0$ and 10\%. E0.1; E1; E1.5; E3; E5 and E10 correspond, respectively, to the treatments with ethanolic leaf extract of $M$. opacum (MOLEE) extract in concentrations of $0.1 ; 1.0 ; 1.5 ; 3.0 ; 5.0$ and 10\%. H0.1; H1; H1.5; H3; H5 and H10 correspond, respectively, to treatments with hexanic extract of M. opacum (MOLEH) in concentrations of 0.1 ; $1.0 ; 1.5 ; 3.0 ; 5$ and $10 \%$. C corresponds to the control

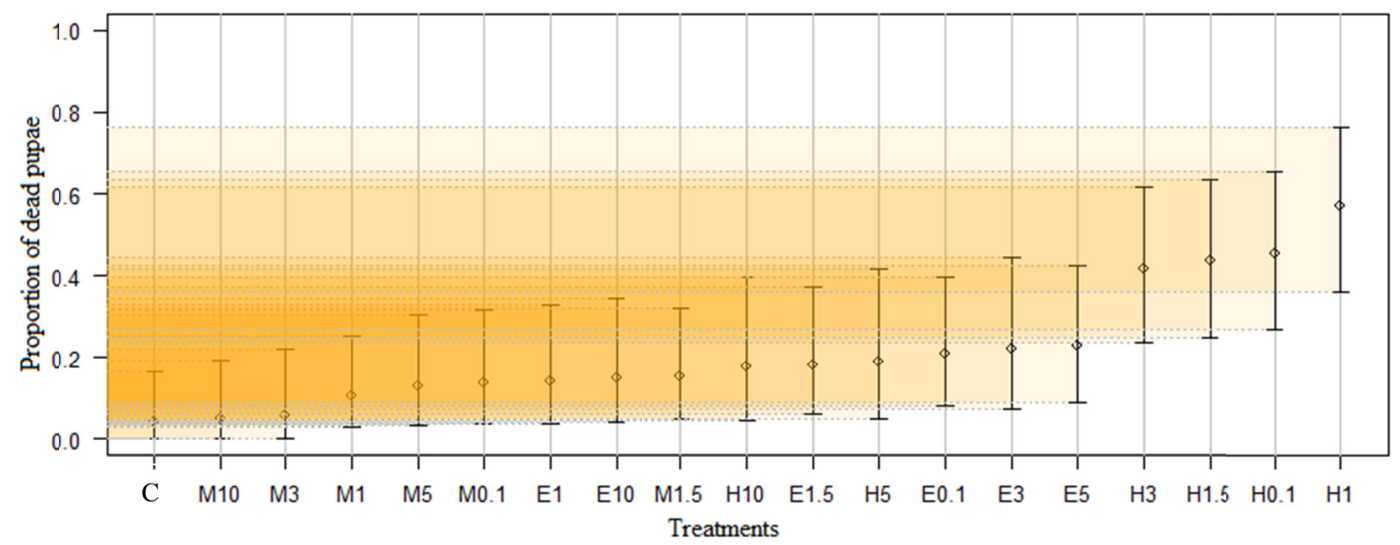

Figure 2. Medians and intervals with 95\% confidence for the proportion of dead pupae of Spodoptera frugiperda for each treatment. M0.1; M1; M1.5; M3; M5 and M10 correspond, respectively, to the treatments with methanolic leaf extract of Machaerium opacum (MOLEM) in concentrations of $0.1 ; 1.0 ; 1.5 ; 3.0 ; 5.0$ and $10 \%$.

E0.1; E1; E1.5; E3; E5 and E10 correspond, respectively, to the treatments with ethanolic leaf extract of $M$. opacum (MOLEE) extract in concentrations of $0.1 ; 1.0 ; 1.5 ; 3.0 ; 5.0$ and 10\%. H0.1; H1; H1.5; H3; H5 and H10 correspond, respectively, to treatments with hexanic extract of M. opacum (MOLEH) in concentrations of 0.1 ;

$1.0 ; 1.5 ; 3.0 ; 5$ and $10 \%$. C corresponds to the control

Significant differences were observed between the treatments as regards larval and pupal mortality. The experimental data related to larval and pupal mortality did not indicate a dose-dependent relationship for any of the fractions of the extracts tested. None of the treatments promoted significant alterations in the sex ratio $($ ( $/ \widehat{\delta})$ of S. frugiperda when compared with the control and nor did they promote noticeable anomalies in the insect (Table 4).

Table 4. Sumary of the statistical analyzes on larval and pupal mortality, sexual ratio and anomalies in Spodoptera frugiperda population treated with extracts of Machaerium opacum

\begin{tabular}{llllll}
\hline Variable & Deviance & d.f.(treatment) & Residual d.f.(nul//reatment) & Residual deviance $_{\text {(nul//reatment) }}$ & p-value \\
\hline Larval mortality & 33.782 & 18 & $569 / 551$ & $661.10 / 627.32$ & 0.0134 \\
Pupal mortality & 51.160 & 18 & $414 / 396$ & $431.44 / 380.27$ & $<0.01$ \\
Sex ratio $(+/ \hat{\jmath})$ & 24.783 & 18 & $325 / 307$ & $451 / 426.84$ & 0.131 \\
Anomalies in the insect & 26.729 & 18 & $235 / 307$ & $109.245 / 82.516$ & 0.0842 \\
\hline
\end{tabular}




\section{Discussion}

Our results showed that the different fractions of $M$. opacum extracts presented an antibiosis effect against $S$. frugiperda. Independently of the polarity of the solvent used in fractionating the leaf extract of M. opacum ingested by the larvae, significant reductions in larval and pupal weight occurred in S. frugiperda when compared to the control, indicating that compounds isolated by specific solvent, or in synergy, had an antibiosis effect on the juvenile phase of this insect.

In general, higher concentrations of the ingested extracts led to lower weight among larvae and pupae. In relation to chronological alterations of the cycle (larval, pupal, adult longevity and total cycle), the ingestion of different fractions and concentrations of extracts promoted alterations in the duration of the larval and pupal phase. The delay in insect development occurs in function of specific components of the plant extract that compromise the hormonal system that regulates the insect's ecdysis process (Trindade, Marques, Xavier, \& Oliveira, 2000). The difference in reductions in adult longevity and in duration of the total cycle was remarkable, with all the treatments differing significantly from the control. This significant effect of the extract on the adult stage of the insect, according to Campos and Boiça Junior (2012), indicates the influence of the natural product on vital functions of the insect in this phase of its development.

The compounds identified in the hexanic fraction (mixed triterpenes, $\alpha$-amyrin and $\beta$-amyrin), lupeol and phytol may have had deleterious effects on the population of $S$. frugiperda. For example, report the presence of epicuticular wax crystals in plants of Ricinus communis, which contain significant quantities of lupeol, possibly involved in the protection of the plant against herbivores (Guhling, Hobl, Yeats, \& Jetter, 2006). Mass spectra with triterpene characteristics such as that verified in our work ( $\alpha$-amyrin and $\beta$-amyrin) were observed in Brazil nut (Bertholletia excelsa), and these may also be involved in plant protection (Siqueira, Pereira, \& Aquino Neto, 2003).

Some concentrations of the methanolic fraction also compromised pupal development. In the methanolic fraction the substance rutin was identified and isolated, and this flavonoid is known to have an insecticidal effect. It is known that some flavonoids can act as phagodeterrents, for example ermanin and rutin (Echeverri et al., 1991; Silva et al., 2016) and as insect growth-inhibitors (Simmonds, 2003), probably because they interfere in neural mechanisms, whose toxic activity is influenced by the chemical structure of the specific compound. Tian and Mclaughlin (2000) mention the flavonoids acacetin, secundiflorol, isovestitol, mucronulatol and isomucronulatol as the possible bioactives that confer resistance on the wood of Robina pseudoacacia (Fabaceae) to deterioration agents, including insects.

Coumarin, also detected in the phytochemical prospection of $M$. opacum, is known for inhibiting the electron transport chain (Neal \& Wu, 1994), and it also compromises the detoxification capacity of insects, which reduces their tolerance to xenobiotics, for example (Moreira et al., 2007). According to Martinez and Emden (2001), the reduction in the weight and development of the larval and pupal phases is due to the reduced ingestion of foods and the low ability to convert nutrients into insect growth and development, resulting from the ingestion of the toxic extract.

In relation to the variables larval and pupal mortality in S. frugiperda, our results did not highlight any fraction of the M. opacum extract. However, the hexanic fractions were always those that promoted the greatest mortality of individuals, in absolute terms. In the present study there was also no significant relationship seen between the dose of the fractions of plant extract and the mortality of larvae and pupae. This dose-independent relationship between plant extracts and mortality is common, as mentioned by Sousa Neto et al. (2018). That author reports that concentrations of plant extract fractions that have high potential to kill larvae and pupae of Helicoverpa armigera (Hübner, 1805) (Lepidoptera: Nostuidae) can still present a phagostimulant effect. A substance of this nature would be interesting as a tool in pest management, since it would stimulate the larvae to ingest the toxic extract when applied on the crop in question.

The fractions and different concentrations of M. opacum extracts did not affect the sex ratio of the $S$. frugiperda population, and nor did they differ significantly from the control. Although Deviance analysis did not present significant differences in the deformity of $S$. frugiperda adults fed with the different extracts in different concentrations, the hexanic extract at its highest concentration (10\%) stood out visibly from the others, which reinforces the need for complementary studies to investigate this important deleterious effect, which is commonly reported when larvae are fed on potentially insecticidal plants (Nathala \& Dinhgra, 2006; Knaak, Tagliari, Machado, \& Fiuza, 2012; Sousa Neto et al., 2018).

An antifeedant effect on S. frugiperda larvae was not verified for the extracts of M. opacum. None of the treatments presented effects of repellence, motion stimulation, suppression or deterrence on the larvae, when 
compared to the control treatment. Some treatments, in absolute terms, presented higher attractiveness than the control treatment, suggesting that they had a phagostimulant effect. If we consider the need to ingest the insecticidal compound, this condition is important for possible pest control action, since the extracts could be sprayed on the crop and the larvae would then ingest them.

\section{Conclusion}

Our results highlight that the ingestion of $M$. opacum extracts promotes significant deleterious alterations in the biology of S. frugiperda; they may, therefore, present potential as an alternative control agent of this pest.

\section{References}

Aguiar-Menezes, E. (2005). Inseticidas botânicos: Seus princípios ativos, modo de ação e uso agrícola. Seropédica, Brasil: Embrapa Agrobiologia.

Amen, Y. M., Marzouk, A. M., Zaghloul, M. G., \& Afifi, M. S. (2015). The genus Machaerium (Fabaceae): Taxonomy, phytochemistry, traditional uses and biological activities. Natural Product Research, 29, 1388-1405. https://doi.org/10.1080/14786419.2014.1003062

Andrews, K. L. (1980). The whorlworm, Spodopetera frugiperda, in Central America and neighboring areas. Florida Entomologist, 63, 456-467. https://doi.org/10.2307/3494530

Baska, K., \& Ignacimuthu, S. (2012). Antifeedant, larvicidal and growth inhibitory effects of ononitol monohydrate isolated from Cassia tora L. against Helicoverpa armigera (Hub.) and Spodoptera litura (Fab.) (Lepidoptera: Noctuidae). Chemosphere, 88, 384-388. https://doi.org/10.1016/j.chemosphere.2012.02.051

Baskar, K., Kingsley, S., Vendan, S. E., Paulraj, M. G., Duraipandiyan, V., \& Ignacimuthu, S. (2009). Antifeedant, larvicidal and pupicidal activities of Atalantia monophylla (L.) Correa against Helicoverpa armigera (Hubner) (Lepidoptera: Noctuidae). Chemosphere, 75, 355-359. https://doi.org/10.1016/ j.chemosphere.2008.12.034

Bernardi, O., Bernardi, D., Horikoshi, R. J., \& Omoto, C. (2016). Manejo da resistência de insetos a plantas Bt. Engenheiro Conceição, Brasil: Promip.

Bettiol, W., \& Morandi, A.B. (2009). Biocontrole de doenças de plantas: uso e perspectivas. Jaguariúna, Brasil: Embrapa Meio Ambiente.

Campos, A. P., \& Boiça Júnior, A. L. (2012). Lagartas de Spodoptera frugiperda (J. E. Smith) (Lepidoptera: Noctuidae) submetidas a diferentes concentrações de óleo de nim. Revista Brasileira de Milho e Sorgo, 11, 137-144. https://doi.org/10.18512/1980-6477/rbms.v11n2p137-144

Costa, A. F. (2001). Farmacognosia (3rd ed.). Lisboa, Portugal: Fundação Calouste Gulbenkian.

Dequech, S. T. B., Sausen, C. D., Lima, C. G., \& Egewarth, R. (2008). Efeito de extratos de plantas com atividade inseticida no controle de Microtheca ochroloma Stal (Col.: Chrysomelidae), em laboratório. Biotemas, 21, 22-31. https://doi.org/10.5007/2175-7925.2008v21n1p41

Duke, J. A. (1981). Handbook of legumes of economic importance. New York, USA: Plenum Press. https://doi.org/10.1007/978-1-4684-8151-8

Echeverri, F., Cardona, G., Torres, F., Pelaez, C., Quiñones, W., \& Renteria, E. (1991). Ermanin: An insect deterrent flavonoid fron Passiflora foetida resin. Phytochemistry, 30, 153-155. https://doi.org/10.1016/ 0031-9422(91)84116-A

Ferraz, S., Lopes, E. A., \& Amora, D. X. (2008). Controle de fitonematóides com o uso de extratos e óleos essenciais de plantas. In L. S. Poltronieri, \& A. K. N. Ishida (Eds.), Métodos alternativos de controle de insetos-praga, doenças e plantas daninhas: panorama atual e perspectivas na agricultura (pp. 153-186). Belém, Brasil: Embrapa Amazônia Oriental.

Flora do Brasil. (2018). Flora do Brasil 2020 em construção. Rio de Janeiro, Brazil: Jardim Botânico do Brasil.

González-Coloma, A., Reina, M., Gutiérrez, C., \& Fraga, B. M. (2002). Natural insecticides: Structure diversity, effects and structure-activity relationships: A case study. Studies in Natural Products Chemistry, 26, 849-879. https://doi.org/10.1016/S1572-5995(02)80020-5

Guhling, O., Hobl, B., Yeats, T., \& Jetter, R. (2006). Cloning and characterization of a lupeol synthase involved in the synthesis of epicuticular wax crystals on stem and hypocotyl surfaces of Ricinus communis. Archives of Biochemistry and Biophysics, 448, 60-72. https://doi.org/10.1016/j.abb.2005.12.013 
Jelihovschi, E. G., Faria, J. C., \& Allaman, I. B. (2014). ScottKnott: A package for performing the Scott-Knott clustering algorithm in R. Trends in Applied and Computational Mathematics, 15, 3-17. https://doi.org/ 10.5540/tema.2014.015.01.0003

Kasten Junior, A. A., Precetti, C. M., \& Parra, J. R. P. (1978). Dados biológicos comparativos de Spodoptera frugiperda em duas dietas artificiais e substrato natural. Revista de Agricultura, 53, 68-78.

Knaak, N., Tagliari, M. S., Machado, V., \& Fiuza, L. M. (2012). Atividade inseticida de extratos de plantas medicinais sobre Spodoptera frugiperda (J. E. Smith) (Lepidoptera: Noctuidae). BioAssay, 7, 1-6. https://doi.org/10.14295/BA.v7.0.63

Koul, O. (2005). Insect antifeedants. Boca Raton, USA: CRC Press. https://doi.org/10.1201/9780203414569

Leatemia, J. A., \& Isman, M. B. (2004). Insecticidal activity of crude seed extracts of Annona spp. Lansium domesticum and Sandoricum koetjape against lepidopteran larvae. Phytoparasitica, 32, 30-37. https://doi.org/10.1007/BF02980856

Lewis, G. P. (2005). Caesalpiniae. In G. P. Lewis, B. Schrire, B. Mackinder, \& M. Lock (Eds.), Legumes of the world (pp. 127-167). Kew, UK: Royal Botanic Gardens.

Mar, G. D., Marchetti, M. E., Souza, L. C. F., Gonçalves, M. C., \& Novelino, J. O. (2003). Produção do milho safrinha em função de doses e épocas de aplicação de nitrogênio. Bragantia, 62, 267-274. https://doi.org/ $10.1590 /$ S0006-87052003000200012

Martínez, A. M., Aguado-Pedraza, A. J., Viñuela, E., Rodríguez-Enríquez, C. L., Lobit, P., Gómez, B., \& Pineda, S. (2017). Effects of ethanolic extracts of Argemone ochroleuca (Papaveraceae) on the food consumption and development of Spodoptera frugiperda (Lepidoptera: Noctuidae). Florida Entomologist, 100, 339-345. https://doi.org/10.1653/024.100.0232

Martinez, S. S., \& Emden, H. F. (2001). Growth disruption, abnormalities and mortality of Spodoptera littoralis (Boisduval) (Lepidoptera: Noctuidae) caused by Azadirachtin. Neotropical Entomology, 30, 113-125. https://doi.org/10.1590/S1519-566X2001000100017

Matos, F. J. A. (2009). Introdução à fitoquímica experimental (3rd ed.). Fortaleza, Brasil: UFC.

Matos, J. M. D., \& Matos, M. E. (1989). Farmacognosia. Fortaleza, Brasil: UFC.

Moreira, M. D., Picanço, M. C., Barbosa, L. C. A., Guedes, R. N. C., Campos, M. R., Silva, G. A., \& Martins, J. C. (2007). Plant compounds insecticide activity against Coleoptera pests of stored products. Pesquisa Agropecuária Brasileira, 42, 909-915. https://doi.org/10.1590/S0100-204X2007000700001

Nathala, E., \& Dhingra, S. (2006). Biological effects of Caesalpinia crista seed extracts on Helicoverpa armigera (Lepidoptera: Noctuidae) and its predator, Coccinella septempunctata (Coleoptera: Coccinellidae). Journal of Asia-Pacific Entomology, 9, 159-164. https://doi.org/10.1016/S1226-8615(08)60287-3

Neal, J. J., \& Wu, D. (1994). Inhibition of insect cytochromes P450 by furanocoumarins. Pesticide Biochemistry and Physiology, 50, 43-50. https://doi.org/10.1006/pest.1994.1056

$\mathrm{R}$ Core Team. (2018). R: A language and environment for statistical computing. R Foundation for Statistical Computing, Vienna, Austria.

Santos, R. G. (2017). Avaliação das atividades tóxica, citotóxica, antimicrobiana e inseticida das folhas de Machaerium opacum Vogel (Fabaceae). Anápolis, Brasil: UEG. https://doi.org/10.14808/sci.plena. 2017.039901

Silva, T. R. F. B., Almeida, A. C. S., Moura, T. L., Silva, A. R., Freitas, S. S., \& Jesus, F. G. (2016). Effect of the flavonoid rutin on the biology of Spodoptera frugiperda (Lepidoptera: Noctuidae). Acta Scientiarum, 38 , 165-170. https://doi.org/10.4025/actasciagron.v38i2.27956

Simmonds, M. S. J. (2003). Flavonoid-insect interactions: Recent advances in our knowledge. Phytochemistry, 64, 21-30. https://doi.org/10.1015/j.bse.2004.12.022

Simões, C. M. O. (2010). Farmacognosia: Da planta ao medicamento (6th ed.). Florianópolis, Brasil: UFSC.

Siqueira, D. S., Pereira, A. S., \& Aquino Neto, F. R. (2003). Determinação de compostos de massa molecular alta em folhas de plantas da Amazônia. Química Nova, 26, 633-640. https://doi.org/10.1590/S010040422003000500002 
Sousa Neto, M., Silva, F. C., Almeida, A. C. S., Menezes, A. C. S., Araújo, M. S., \& Jesus, F. G. (2018). Toxicity of Andira paniculata (Fabaceae) extracts to Helicoverpa armigera (Lepidoptera: Noctuidae). Journal of Agriculture Science, 10(6), 248-258. https://doi.org/10.5539/jas.v10n6p264

Souza, B. R., Coelho, G. M., Rocha, E. C., Jesus, F. G., Menezes, A. C. S., \& Araújo, M. S. (2017). Topical toxicity of Esenbeckia pumila extracts on leaf-cutting ants Atta laevigata and Acromyrmex balzani. Journal of Agriculture Science, 9(12), 248-258. https://doi.org/10.5539/jas.v9n12p248

Tian, F., \& McLaughlin, J. L. (2000). Bioactive flavonoids from the black locust tree Robinia pseudoacacia. Pharmaceutical Biology, 38, 229-234. https://doi.org/10.1076/1388-0209(200007)3831-SFT229

Trindade, R. C. P., Marques, I. M. R., Xavier, H. S., \& Oliveira, J. V. (2000). Extrato metanólico da amêndoa da semente de nim e a mortalidade de ovos e lagartas da traça-do-tomateiro. Scientia Agricola, 57, 407-413. https://doi.org/10.1590/S0103-90162000000300006

Upadhyay, R. K. (2012). Insecticidal and oviposition inhibition efficacy of Capparis deciduato Sitophilus oryzae Linn. (Coleoptera: Curculionidae). International Journal of Chemical and Biochemical Science, 2, 14-23.

Wink, M. (2013). Evolution of secondary metabolites in legumes (Fabaceae). South African Journal of Bototany, 89, 164-175. https://doi.org/10.1016/j.sajb.2013.06.006

\section{Copyrights}

Copyright for this article is retained by the author(s), with first publication rights granted to the journal.

This is an open-access article distributed under the terms and conditions of the Creative Commons Attribution license (http://creativecommons.org/licenses/by/4.0/). 